\title{
Original Article \\ Clinical Profile of Ascites based on Presentation and Laboratory Findings: An Institutional Experience from Kathmandu, Nepal
}

\author{
Rinku Joshi ${ }^{1}$, Dhan Bahadur Shrestha ${ }^{2}$, Rajib Pande ${ }^{1}$, Sukriti Maharjan² \\ ${ }^{1}$ Department of Medicine, Shree Birendra Hospital, Chhauni, Nepalese Army Institute of Health \\ Sciences, Kathmandu, Nepal, ${ }^{2}$ Intern, Shree Birendra Hospital, Chhauni; NAIHS, Kathmandu, Nepal \\ Address for correspondence: Dhan Bahadur Shrestha, Shree Birendra Hospital, Chhauni, Kathmandu, \\ Nepal. Phone: +977-9849943388. E-mail: medhan75@gmail.com
}

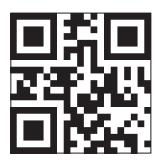

Quick Access Code

How to cite this article: Joshi R, Shrestha DB, Pande R, Maharjan S. Clinical Profile of Ascites based on Presentation and Laboratory Findings: An institutional experience from Kathmandu, Nepal. Journal of Medical Research and Innovation. 2018;2(1):e000101.

DOI: 10.15419/jmri.101

Publication history: Received: 09-11-2017

Accepted: 02-01-2018

Published: 02-01-2018

Editor: Dr. Varshil Mehta

Copyright: Joshi R. This is an open access article distributed under the terms of the Creative Commons Attribution License CC-BY 4.0., which permits unrestricted use, distribution, and reproduction in any medium, provided the original author and source are credited.

Funding: NIL Conflict of Interest: NIL

\section{Abstract}

Introduction: Ascites is the fluid collection in the potential space of the peritoneal cavity. Alcoholic liver disease and intra-abdominal malignancy are two major etiologies behind it. Furthermore, diagnosis of tuberculous ascites should be thought of due to endemicity. Cirrhotic patients, at any time, during the course of the disease, invariably present with ascites, which is one of the marker of decomposition of the ongoing liver disease. In our context, etiology behind ascites and its correlation with symptoms and clinical findings not yet studied so the present study is conceptualized. Methods: This is a crosssectional retrospective descriptive hospital-based record review of patients presented with ascites in a tertiary center of Kathmandu. One hundred fourteen patients with ascites under regular follow-up of Shree Birendra Hospital (SBH) were reviewed. Data regarding presenting complaints, examination findings, relevant investigations during the first visit, and final diagnosis were retrieved from our own record keeping, and recorded information were then evaluated. Results: Patients having ascites have myriad of symptoms and signs, the most common clinical feature icterus (74, 64.9\%). Most of them were anemic at presentation. $42(36.8 \%)$ had high blood urea and $36(31.5 \%)$ with high creatinine suggesting approximately $30-40 \%$ of cases presented with deranged renal function test. 93 (81.5\%) had raised total serum bilirubin. Similarly, PT/INR derangements were in 74 (64.9\%) and 57 (50\%) suggesting deranged liver function. Serum albumin was $<3.5 \mathrm{~g} /$ deciliter in $83(72.8 \%)$ cases. Among the patients studied, 80 (70.1\%) had high SAAG suggesting transudative type of ascites and rest 34 had low SAAG suggesting exudative type of ascites. Overall assessment revealed that majority of patients (71.05\%) had CLD as the cause of ascites. Conclusions: Ascites due to chronic liver disease was the main finding with etiology supported by laboratory findings. Significant numbers of the patients enrolled in the present study had deranged renal parameters in addition to deranged liver function parameters, which suggests that renal functions should also be properly taken care of in patients of ascites.

Keywords: Ascites, Liver cirrhosis, Serum ascetic albumin gradient

\section{Introduction}

Ascites is the fluid collection in the peritoneal cavity. Different pathologies with unique pathomechanism give rise to ascites. Alcoholic liver disease, intra-abdominal malignancy, non-alcoholic cirrhosis, and malignancy with cirrhosis are common causes in descending sequence. ${ }^{[1]}$ Ascites is one spectrum of liver cirrhosis and portal hypertension. Cirrhotic patients at a time invariably present with ascites and are a marker of decompensation. In these cases, severity has to be evaluated and the case should be managed appropriately with salt restriction, diuretics, therapeutic paracenteses, or surgical shunt procedure alone or in combination. ${ }^{[2]}$ Several gastrointestinal and ovarian malignancies present with ascites, and malignant ascites is a grave prognostic sign of the diseased individual with poor survival. ${ }^{[3,4]}$ Due to the endemicity of tuberculosis in Nepal, 
tuberculous peritonitis also needs to be kept in differential and culture growth which is the gold standard test for diagnosis tuberculous peritonitis. ${ }^{[5,6]}$

In our context, etiologies behind ascites and its correlation with symptoms and clinical findings are not yet studied and are still unknown, so the present study is conceptualized to evaluate the cases of ascites in terms of clinical features and laboratory investigations in our setting based on our hospital.

\section{Methods}

This was a cross-sectional retrospective descriptive hospitalbased record review of a tertiary center of Kathmandu. This non-invasive descriptive study was done over records of all new patients presented with ascites in the department of internal medicine over the past 3 years. One hundred fourteen cases of ascites under follow-up of SBH were reviewed. This record review was done over 3 months after the approval of local IRC of Nepalese Army Institute of Health Sciences. After approval from the internal medicine department and IRC, proper reviewing of the cases started. Data regarding presenting symptoms, examination findings, appropriate investigations including non-invasive serum-ascites albumin gradient during first visit, and final diagnosis were retrieved from our own record keeping and recorded information were evaluated. The recorded data were entered thoroughly and analyzed using SPSS version 22 and Excel computer program.

Among the patients of ascites presented in our center, we initially sent baseline blood investigations, namely, complete blood count, random blood sugar, liver biochemistry and liver and renal function tests, and serum electrolytes to evaluate the overall status of the patients along with the functional status of the liver. Furtheemore, specifically to identify the etiology and to approach the case, we also sent hepatitis virus serology, diagnostic tapping of the ascitic fluid, ultrasound of the abdomen, and contrast-enhanced computed tomography of the abdomen when indicated. We followed FDA value for standard laboratory finding interpretation.

\section{Results}

The mean age of the patients studied was $54.89 \pm 12.99$ years with the minimum being 16 years and maximum being 82 years. Among all, 28 (24.6\%) were females, while the rest $86(75.4 \%)$ were males. Patients having ascites have myriad of other clinical features in addition to ascites like jaundice, weight loss, anorexia and abdominal pain etc. The most common clinical feature being icterus $(74,64.9 \%)$ followed by anorexia $(53,46.4 \%)$. Among clinical features, abdominal pain, fever, and icterus had significant association with ascites $(P<0.05)$ [Table 1$]$

Among the patients of ascites evaluated, total leukocyte counts were raised in 24 (21.05\%). Most $(105,92.1 \%)$ of the patients were anemic at presentation based on FDA demarcation. A total of $46(40.35 \%)$ cases were hyponatremic. $42(36.8 \%)$ had high blood urea and $36(31.5 \%)$ with high creatinine suggesting approximately $30-40 \%$ of cases presented with deranged renal function test. $93(81.5 \%)$ had raised total serum bilirubin, while SGPT and SGOT were high in 94 (82.4\%) and $72(63.1 \%)$, respectively. Similarly, PT/INR derangements were in $74(64.9 \%)$ and $57(50 \%)$ suggesting deranged liver function. Serum albumin was $<3.5 \mathrm{~g} /$ deciliter in 83 (72.8\%) cases. Among the patients studied, 80 (70.1\%) had high SAAG suggesting transudative type of ascites and rest 34 had low SAAG suggesting exudative type of ascites. Table 2 presents the findings of the laboratory assessment of the cases of ascites.

Overall assessment revealed that most of the patients (81, 71.5\%) had chronic liver disease as the culprit of ascites. Among them 5 had chronic hepatitis B virus-related hepatitis while rest 76 had alcohol-related liver disease. Other causes of ascites were tubercular peritonitis, right heart failure, and intra-abdominal malignancies including carcinoma stomach, carcinoma ovary, hepatocellular carcinomas, and pancreatic cancer.

Most of the cases of CLD had transudative type of ascites (high SAAG), and in other cases, it was exudative (low SAAG), and the $P$-value was correlated [Table 3].

\section{Discussion}

Ascites is a lethal presentation, with myriad of cause behind. This presentation is common all over the world in medical practice. Its early detection is required to ensure effective management without any complications.

In our case, among 114 cases of ascites studied, $71.05 \%$ were due to chronic liver disease, while $15.7 \%$ were due to abdominal malignancies. Other studies also show somehow similar results with CLD representing about $80 \%$ of the cases while malignant ascites accounting $10 \%$ of the cases..$^{[7,8]}$ In contrast, another study from northern India showed cirrhosis to be the predominant cause of ascites $(60.78 \%)$, followed by tuberculosis (15.68\%), and rest $37 \%$ being other causes. ${ }^{[9]}$

Similarly, another Indian study concluded cirrhosis and tuberculous ascites being common etiology of ascites. ${ }^{[10]}$

The overall laboratory parameters were not assessed in the previous studies to accurately depict the clinical condition of the patient, whereas the present study attempts to show the clinical profile of the ascites patients to predict the physiological status of the patients. This study showed about $40 \%$ of the cases had hyponatremia and $30-40 \%$ of the cases had deranged renal function which suggests that fluid and electrolyte balance as well as dose of medications such as diuretics need to be calculated meticulously. Our data showed the deranged liver function in $60-80 \%$ of the cases, 
Table 1: Sign and symptoms at presentation among cases of ascites

\begin{tabular}{|c|c|c|c|c|c|c|c|}
\hline Variables & Features & CLD & Right heart failure & Abdominal malignancies & Tubercular peritonitis & Total & $P$ value \\
\hline \multirow[t]{2}{*}{ Weight loss } & No & 58 & 5 & 10 & 3 & 76 & 0.067 \\
\hline & Yes & 23 & 1 & 8 & 6 & 38 & \\
\hline \multirow[t]{2}{*}{ Pruritus } & No & 74 & 5 & 17 & 9 & 105 & 0.658 \\
\hline & Yes & 7 & 1 & 1 & 0 & 9 & \\
\hline \multirow[t]{2}{*}{ Anorexia } & No & 46 & 3 & 10 & 2 & 61 & 0.266 \\
\hline & Yes & 35 & 3 & 8 & 7 & 53 & \\
\hline \multirow[t]{2}{*}{ Abdominal pain } & No & 49 & 6 & 7 & 3 & 65 & 0.024 \\
\hline & Yes & 32 & 0 & 11 & 6 & 49 & \\
\hline \multirow[t]{2}{*}{ Myalgia } & No & 72 & 5 & 14 & 8 & 99 & 0.639 \\
\hline & Yes & 9 & 1 & 4 & 1 & 15 & \\
\hline \multirow[t]{2}{*}{ Nausea and vomiting } & No & 46 & 5 & 9 & 6 & 66 & 0.497 \\
\hline & Yes & 35 & 1 & 9 & 3 & 48 & \\
\hline \multirow[t]{2}{*}{ Fever } & No & 66 & 6 & 13 & 4 & 89 & 0.036 \\
\hline & Yes & 15 & 0 & 5 & 5 & 25 & \\
\hline \multirow[t]{2}{*}{ Dark-colored urine } & No & 65 & 6 & 12 & 9 & 92 & 0.117 \\
\hline & Yes & 16 & 0 & 6 & 0 & 22 & \\
\hline \multirow[t]{2}{*}{ Pallor } & No & 60 & 5 & 13 & 6 & 84 & 0.909 \\
\hline & Yes & 21 & 1 & 5 & 3 & 30 & \\
\hline \multirow[t]{2}{*}{ Splenomegaly } & No & 64 & 5 & 15 & 9 & 93 & 0.486 \\
\hline & Yes & 17 & 1 & 3 & 0 & 21 & \\
\hline \multirow[t]{2}{*}{ Icterus } & No & 22 & 4 & 6 & 8 & 40 & 0.0009 \\
\hline & Yes & 59 & 2 & 12 & 1 & 74 & \\
\hline \multirow[t]{2}{*}{ Leukonychia } & No & 74 & 5 & 16 & 9 & 104 & 0.692 \\
\hline & Yes & 7 & 1 & 2 & 0 & 10 & \\
\hline \multirow[t]{2}{*}{ Spider naevi } & No & 71 & 6 & 18 & 9 & 104 & 0.215 \\
\hline & Yes & 10 & 0 & 0 & 0 & 10 & \\
\hline \multirow[t]{2}{*}{ Hepatomegaly } & No & 61 & 5 & 14 & 9 & 89 & 0.393 \\
\hline & Yes & 20 & 1 & 4 & 0 & 25 & \\
\hline
\end{tabular}

predisposition to hypoglycemia as well as bleeding episodes either due to rupture esophageal varices in cirrhotic cases or due to deranged clotting profile as depicted by PT/INR values. Hence, these simple parameters should also be taken care of when a case of ascites present.

Of the patients studied, 80 (70.1\%) had transudative, and rest $34(29.9 \%)$ had exudative type of ascites. Similar findings were shown by a study from Bihar, India. ${ }^{[11]}$ SAAG is the important test in patients in whom cause of ascites is still need to be rectified. SAAG value strongly correlates with the etiology, whether it is due to CLD or other pathology like malignancies and whether the ascites is transudative or exudative. ${ }^{[11,12]}$ In our study, among the CLD patients, most of them had transudative ascites while 12 patients had exudative ascites, indicating concurrent SBP, where SAAG findings correlates the diagnosis $(P=0.000)$. Similarly, among patients with coexisting heart failure with TB peritonitis, SAAG was low. SAAG was high in patients with intra- abdominal malignancy overlapping with CLD. All tubercular peritonitis patients had exudative form of ascites.

The findings obtained from this study are inferenced from single-centered small-sized cross-sectional study, so clinical and laboratory findings need to be studied in larger population to put concluding remarks to guide approach of the ascitic patients.

\section{Conclusions}

The study highlights chronic liver disease as the most common culprit for ascites, which follows abdominal malignancies. It also correlates etiology of ascites with the simple and noninvasive laboratory parameters like serum albumin ascites gradient among others. Significant numbers of the patients had deranged renal function on top of deranged liver function, so these parameters need to be taken care of. 
Table 2: Laboratory parameters

\begin{tabular}{|c|c|c|c|c|c|c|c|}
\hline Variables & Features & CLD & Right heart failure & $\begin{array}{c}\text { Abdominal } \\
\text { malignancies }\end{array}$ & $\begin{array}{l}\text { Tubercular } \\
\text { peritonitis }\end{array}$ & Total & $P$ value \\
\hline \multirow[t]{3}{*}{ Total count } & $<4000$ & 3 & 1 & 4 & 0 & 8 & 0.050 \\
\hline & Normal (4-11000) & 62 & 5 & 9 & 6 & 82 & \\
\hline & $>11000$ & 16 & 0 & 5 & 3 & 24 & \\
\hline \multirow[t]{2}{*}{ Hemoglobin } & $\mathrm{M}(14-17.5) \mathrm{F}(12.3-15.3)$ & 8 & 0 & 1 & 0 & 9 & 0.602 \\
\hline & Anemic & 73 & 6 & 17 & 9 & 105 & \\
\hline \multirow{3}{*}{$\begin{array}{l}\text { Random blood } \\
\text { sugar }\end{array}$} & Normal (99-140) & 44 & 4 & 8 & 6 & 62 & 0.691 \\
\hline & $<99$ & 23 & 2 & 6 & 3 & 34 & \\
\hline & $>140$ & 14 & 0 & 4 & 0 & 18 & \\
\hline \multirow[t]{2}{*}{ Urea } & Normal (20-40) & 52 & 1 & 12 & 7 & 72 & 0.088 \\
\hline & High & 29 & 5 & 6 & 2 & 42 & \\
\hline \multirow[t]{2}{*}{ Creatinine } & Normal (.6-1.1) & 55 & 2 & 14 & 7 & 78 & 0.210 \\
\hline & High (>1.1) & 26 & 4 & 4 & 2 & 36 & \\
\hline \multirow[t]{3}{*}{$\mathrm{Na}+$} & Normal (135-147) & 43 & 3 & 13 & 8 & 67 & 0.401 \\
\hline & Low $(<135)$ & 37 & 3 & 5 & 1 & 46 & \\
\hline & High (>147) & 1 & 0 & 0 & 0 & 1 & \\
\hline \multirow[t]{3}{*}{$\mathrm{K}+$} & Normal (3.5-5.5) & 69 & 5 & 17 & 9 & 100 & 0.626 \\
\hline & Hypokalemia & 9 & 1 & 0 & 0 & 10 & \\
\hline & Hyperkalemia & 3 & 0 & 1 & 0 & 4 & \\
\hline \multirow{2}{*}{$\begin{array}{l}\text { Total serum } \\
\text { bilirubin }\end{array}$} & Normal $(<1)$ & 4 & 4 & 6 & 7 & 21 & 0.000 \\
\hline & High $(>1)$ & 77 & 2 & 12 & 2 & 93 & \\
\hline \multirow{2}{*}{$\begin{array}{l}\text { Direct serum } \\
\text { bilirubin }\end{array}$} & Normal $(<0.4)$ & 5 & 3 & 7 & 6 & 21 & 0.000 \\
\hline & High (>0.4) & 76 & 3 & 11 & 3 & 93 & \\
\hline \multirow[t]{2}{*}{ SGPT } & Normal (0-30U/L) & 10 & 3 & 5 & 2 & 20 & 0.062 \\
\hline & High (>30U/L) & 71 & 3 & 13 & 7 & 94 & \\
\hline \multirow[t]{2}{*}{ SGOT } & Normal (0-40) & 21 & 5 & 10 & 6 & 42 & 0.001 \\
\hline & High (>40 U/L) & 60 & 1 & 8 & 3 & 72 & \\
\hline \multirow[t]{2}{*}{ ALP } & Normal (50-160) & 48 & 5 & 11 & 3 & 67 & 0.267 \\
\hline & High (>160 U/L) & 33 & 1 & 7 & 6 & 47 & \\
\hline \multirow[t]{2}{*}{ Prothrombin } & Normal (9.5-13.5) & 21 & 4 & 9 & 6 & 40 & 0.010 \\
\hline & High (prolonged) & 60 & 2 & 9 & 3 & 74 & \\
\hline \multirow[t]{2}{*}{ INR } & Normal $(<1.3)$ & 29 & 4 & 15 & 9 & 57 & 0.000 \\
\hline & Prolonged & 52 & 2 & 3 & 0 & 57 & \\
\hline \multirow[t]{2}{*}{ Serum protein } & Normal (6.3-8) & 42 & 5 & 3 & 6 & 56 & 0.0083 \\
\hline & Low $(<6.3)$ & 39 & 1 & 15 & 3 & 58 & \\
\hline \multirow[t]{2}{*}{ Serum albumin } & Normal (3.5-5.5) & 24 & 2 & 4 & 1 & 31 & 0.624 \\
\hline & Low $(<3.5)$ & 57 & 4 & 14 & 8 & 83 & \\
\hline \multirow[t]{2}{*}{ HbsAg } & Negative & 77 & 6 & 17 & 9 & 109 & 0.848 \\
\hline & Positive & 4 & 0 & 1 & 0 & 5 & \\
\hline \multirow[t]{2}{*}{ Ascitic protein } & $>2.5 \mathrm{~g} / \mathrm{dl}$ & 52 & 3 & 11 & 0 & 66 & 0.003 \\
\hline & $\geq 2.5 \mathrm{~g} / \mathrm{dl}$ & 29 & 3 & 7 & 9 & 48 & \\
\hline \multirow[t]{2}{*}{ SAAG } & Exudative $(\leq 1.1)$ & 12 & 4 & 9 & 9 & 34 & 0.000 \\
\hline & Transudative (>1.1 mg/dl) & 69 & 2 & 9 & 0 & 80 & \\
\hline
\end{tabular}


Table 3: SAAG correlating with diagnosis

\begin{tabular}{lcccc} 
Diagnosis & Exudative & Transudative & Total & P value \\
CLD & 12 & 69 & 81 & 0.000 \\
$\begin{array}{l}\text { Congestive heart } \\
\text { failure }\end{array}$ & 4 & 2 & 6 & \\
$\begin{array}{l}\text { Abdominal } \\
\text { malignancies }\end{array}$ & 9 & 9 & 18 & \\
$\begin{array}{l}\text { Tubercular } \\
\text { peritonitis }\end{array}$ & 9 & 0 & 9 & \\
Total & 34 & 80 & 114 & \\
\hline
\end{tabular}

\section{References}

1. Khan J, Pikkarainen $P$, Karvonen $A L$, Mäkelä $T$, Peräaho $M$, Pehkonen E, et al. Ascites: Aetiology, mortality and the prevalence of spontaneous bacterial peritonitis. Scand J Gastroenterol 2009;44:970-4.

2. Biecker E. Diagnosis and therapy of ascites in liver cirrhosis. World J Gastroenterol 2011;17:1237.

3. Ayantunde AA, Parsons SL. Pattern and prognostic factors in patients with malignant ascites: A retrospective study. Ann Oncol 2007;18:945-9.

4. Sangisetty SL, Miner TJ. Malignant ascites: A review of prognostic factors, pathophysiology and therapeutic measures. World J Gastrointest Surg 2012;4:87.

5. Vardareli E, Kebapcı M, Saricam T, Pasaoglu Ö, Acikalin M. Tuberculous peritonitis of the wet ascitic type: Clinical features and diagnostic value of image-guided peritoneal biopsy. Dig Liver Dis 2004;36:199-204.

6. Sanai FM, Bzeizi KI. Systematic review: Tuberculous peritonitis-presenting features, diagnostic strategies and treatment. Aliment Pharmacol Ther 2005;22:685-700.

7. Hwangbo Y, Jung JH, Shim J, Kim BH, Jung SH, Lee CK, et al. Etiologic and laboratory analyses of ascites in patients who underwent diagnostic paracentesis. Korean J Hepatol 2007;13:185-95.

8. Ayantunde AA, Parsons SL. Pattern and prognostic factors in patients with malignant ascites: A retrospective study. Ann Oncol 2007; 18:945-9.

9. Mehra D, Thakur D, Sultania S, Chaturvedi A, Agarwal G, Kumar A. Etiology of ascites in adults living in Rohilkhand region, India: A hospital-based study. Int J Adv Res 2016;2:1-4.

10. Kumar B, Sharma B, Raina S, Sharma N, Gupta D, Mardi K. Etiology of ascites in adults living in the hills of Himachal Pradesh, India: A hospital-based study. Chrismed J Health Res 2016;3:41.

11. Suman S, Jyoti D, Agrawal PK, Bhattacharya BK. Clinicopathological correlation of serum ascites albumin gradient with ascitic fluid total protein in patients of ascites with portal hypertension attending a tertiary care hospital in Eastern Bihar, India. Int J Adv Med 2017;4:842-6.

12. Tarn AC, Lapworth R. Biochemical analysis of ascitic (peritoneal) fluid: What should we measure? Ann Clin Biochem 2010;47:397-407. 